Original Research Article

\title{
Evaluation of anti-inflammatory activity of ethanolic extract of Gmelina arborea in experimental acute and sub-acute inflammatory models in wistar rats
}

\author{
Priya Gandigawad ${ }^{1}$, Basavaraj Poojar ${ }^{2}$, Nandan Hodlur ${ }^{3}$, Ravi K. Sori ${ }^{1 *}$
}

\begin{abstract}
${ }^{1}$ Department of Pharmacology, SDM College of Medical

Sciences and Hospital,

Dharwad, Karnataka, India

${ }^{2}$ Department of Pharmacology,

Kasturba Medical College

Mangalore (Manipal Academy

of Higher Education),

Karnataka, India

${ }^{3}$ Department of Dravyaguna,

BVVS Ayurvedic Medical

College and Hospital, Bagalkot,

Karnataka, India
\end{abstract}

Received: 17 October 2018

Accepted: 29 November 2018

\section{*Correspondence to: \\ Dr. Ravi K. Sori, \\ Email: soriravi@gmail.com}

Copyright: (C) the author(s), publisher and licensee Medip Academy. This is an openaccess article distributed under the terms of the Creative Commons Attribution NonCommercial License, which permits unrestricted noncommercial use, distribution, and reproduction in any medium, provided the original work is properly cited.

\begin{abstract}
Background: Inflammation is a complex reaction to various injurious agents such as infections, trauma, foreign bodies, tissue necrosis, physical and chemical agents, that consists of vascular responses, migration and activation of leukocytes and systemic reactions. Non-Steroidal Anti-Inflammatory Drugs (NSAIDs) are currently the most commonly prescribed drugs for treating pain and inflammation. The traditional NSAIDs usually cause various adverse effects on long term use. Gmelina arborea Linn (Gambhari) belongs to family Verbenaceae. The roots, leaves, flowers, fruits and bark are used for treating different ailments as anthelmintic, analgesic, anti-pyretic, antidiabetic, antimicrobial, diuretic and other common disorders.

Methods: The study was carried out by using inflammatory models in wistar rats. The anti-inflammatory activity of $G$. arborea was compared with standard drug aspirin. The study parameters for acute inflammation was assessment of reduction in inflammation \& the percentage inhibition of the paw edema. The parameter for the sub-acute inflammation was percentage inhibition of the dry granuloma weight.

Results: The low and high dose of G. arborea root extract significantly showed the anti-inflammatory activity when compared to control group. The high dose of G. arborea extract showed comparable results in parameters like reducing inflammation, percentage inhibition of paw edema and dry granuloma weight in acute carrageenan paw edema and sub-acute inflammation cotton pellet granuloma models with standard aspirin treated group.

Conclusions: Since G. arborea root extract was having all the qualities required for anti-inflammatory drug. However, no clear inference can be drawn at this stage and hence we consider the work for further extensive research.
\end{abstract}

Keywords: Aspirin, Carrageenan paw edema, Cotton pellet granuloma, Gmelina arborea, Inflammation

\section{INTRODUCTION}

Inflammation is a complex reaction to various injurious agents such as infections, trauma, foreign bodies, tissue necrosis, physical and chemical agents, that consists of vascular responses, migration and activation of leukocytes and systemic reactions. ${ }^{1}$

Inflammation is usually treated by anti-infective agents irrespective of its etiological factor. However, in case of inflammation caused by infection it needs treatment not 
only with anti-infective / antimicrobial but also antiinflammatory agents. In case, antimicrobials possess antiinflammatory activity they would be able to control not only infection but also inflammation provided causative organisms are susceptible to them.

Non-Steroidal Anti-Inflammatory Drugs (NSAIDs) are currently the most commonly prescribed drugs for treating pain and inflammation. They are indeed effective in managing painful inflammatory conditions like osteoarthritis, ankylosing spondylitis, rheumatoid arthritis etc. However, they cause a number of side effects. The traditional NSAIDs usually cause gastrointestinal adverse effects on long term use and the selective cyclooxygenase (COX2) inhibitors are known to possess dangerous cardio toxic potential. Oxidative stress is one of the pivotal mechanisms of AP. Excessive reactive oxygen species (ROS) provoke inflammation. ${ }^{2}$

From olden days, there has been use of plant sources in the treatment of various disease modalities due to their perceived lower side effects, ease of accessibility and affordability. Plants are the indigenous sources for the discovery of new drugs and some have been shown to be promising in the treatment of inflammatory diseases with minimum side effects. Plants with medicinal uses in inflammatory conditions thus need to be screened for potential anti-inflammatory activity. ${ }^{3}$

Gmelina arborea Linn (Gambhari) belongs to family verbenaceae. It is a medium sized, unarmed deciduous tree and can be found throughout India. It is well-known for its medicinal properties in ancient system of Indian medicine. The roots, leaves, flowers, fruits and bark are used for treating different ailments as anthelmintic, analgesic, antipyretic, antidiabetic, antimicrobial, diuretic and other common disorders. As the plant is rich in certain chemical constituents like flavonoids, saponins, terpenoids, lignans, sterols and cardiac glycosides.

Crude extracts of the plant are reported to possess woundhealing properties, antidiarrheal activity, antioxidant activity, antidiabetic activity, and antiulcer activity. ${ }^{4}$ However, little information is available on the effects of G. arborea on inflammation. Therefore, the present study was designed to evaluate the effects of Gmelina arborea on acute and subacute inflammation in albino wistar rats.

\section{METHODS}

An in vivo experimental study conducted after taking the approval from the institutional animal ethics committee 1284/ac14/18/CPCSEA.

\section{Equipment's used}

Feeding tube, plethysmograph, digital weighing machine, surgical instruments and soxhlet apparatus.

\section{Chemicals used}

Ethanol, aspirin tablet from Zydus Cadilla, Carboxymethyl Cellulose (CMC) $0.5 \%$, and Halothane.

\section{Selection of the animal}

Twenty four albino wistar healthy rats were taken from the central animal house for the study. The animals weighed 150 grams to 200 grams \& the animals were housed under standard condition, housed individually with normal water and food granules, 12:12 hours light dark cycle, 50\% humidity and $28^{\circ} \mathrm{C}$ temperature and provided with standard food granules and water ad libitum.

\section{Plant preparation and extraction}

The fresh roots of Gmelina arborea were purchased from the local market and were shade dried and coarsely powdered. The powder is filled in to filter paper bag and placed in the soxhlet apparatus for extraction. The soxhlet apparatus is connected to round bottom flask which is fill by ethanol $(90 \%)$ solvent and water bath to maintain temperature. The ethanol was boiled at $40^{\circ} \mathrm{C}$ for over a period of 24 hours. The extract obtained was $28 \%$ and was stored in desiccator at room temperature.

\section{Sample size}

The minimum number of rats in each group was kept as six, so as to obtain statistically significant results within and between the groups.

\section{Animal grouping and treatment}

Total 24 rats were used in the present study. For acute inflammation 24 rats were used and divided in to 4 groups (6 rats in each group), the same grouping method is followed for subacute inflammation.

\section{Experimental models}

Acute inflammation

Table 1: Animals were divided in to 4 treatment groups 6 rats in each group for acute and subacute inflammation.

\begin{tabular}{|lll|}
\hline $\begin{array}{l}\text { Group } \\
\text { No. }\end{array}$ & $\begin{array}{l}\text { Group name and drugs to be } \\
\text { administered }\end{array}$ & $\begin{array}{l}\text { Number } \\
\text { of rats }\end{array}$ \\
\hline I & Control - Normal saline & 6 \\
\hline II & Standard - Aspirin $200 \mathrm{mg} / \mathrm{kg}$ & 6 \\
\hline III & $\begin{array}{l}\text { Low dose - G.arborea } \\
750 \mathrm{mg} / \mathrm{kg}\end{array}$ & 6 \\
\hline IV & $\begin{array}{l}\text { High dose - G.arborea } \\
1000 \mathrm{mg} / \mathrm{kg}\end{array}$ & 6 \\
\hline
\end{tabular}

All the drugs are given via oral route through feeding tube and animals are dosed once a day with $0.5 \%$ carboxy methyl cellulose as vehicle 
Rats starved overnight with free access to water and divided into four groups ( $\mathrm{n}=6$ in each) to receive various treatments.

Calculated clinical equivalent doses, $200 \mathrm{mg} / \mathrm{kg}$ of aspirin (in aspirin group), $750 \mathrm{mg} / \mathrm{kg}$ of $G$. arborea once daily (in low dose group), $1000 \mathrm{mg} / \mathrm{kg}$ of $G$. arborea once daily (in high dose group) were administered, while the control group normal saline orally. One hour after drug administration, $0.05 \mathrm{ml}$ of carrageenan $(1 \% \mathrm{w} / \mathrm{v})$ in normal saline was injected into the sub plantar region of the left hind paw. ${ }^{5}$ A mark was made on both hind paws just below the tibiotarsal junction, so that the paw could be dipped in the mercury column of the plethysmometer up to the mark to ensure constant paw volume. The paw edema was measured at $0 \mathrm{hr}$ (immediately after injecting carrageenan), and the procedure was repeated at $0.5,1,3$, 4 , and 5 hours. The difference between $0 \mathrm{hr}$ and subsequent reading was taken as actual edema volume.

The percentage inhibition of edema was calculated using formula:

\section{Percentage inhibition of edema mean}

1 - Mean increase in paw volume in treated group $\times 100$ Mean increase in paw volume in control group

\section{Subacute inflammation}

Rats were divided into 4 groups of six in each. After clipping the hair in axillae and groin, under light halothane anaesthesia, two sterile cotton pellets weighing $10 \mathrm{mg}$ each and two sterile grass piths $(25 \mathrm{~mm} \times 2 \mathrm{~mm}$ each $)$ were implanted, subcutaneously through a small incision. Wounds were then sutured and animals were then caged individually after recovery from anaesthesia. Aseptic precautions were taken throughout the experiment. The rats then received calculated clinical equivalent doses, $200 \mathrm{mg} / \mathrm{kg}$ of aspirin once daily (in aspirin group), $750 \mathrm{mg} / \mathrm{kg}$ of $G$. arborea once daily (in low dose group), $1000 \mathrm{mg} / \mathrm{kg}$ of $G$. arborea once daily orally (in high dose group), while the control group received normal saline orally. The treatment was started on the day of implantation and continued for 10 days. On $11^{\text {th }}$ day, the rats were sacrificed with an overdose of anaesthesia to remove the cotton pellets and grass piths. The pellets, free from the extraneous tissue were dried overnight at $60^{\circ} \mathrm{C}$ to note their dry weight. Net granuloma formation was calculated by subtracting the initial weight of cotton pellet from the weights noted. Mean granuloma dry weight for various groups were calculated and expressed in $\mathrm{mg} / 100 \mathrm{~g}$ body weight. ${ }^{6}$

\section{Percentage inhibition of granuloma dry weight}

1 - Dry weight of granuloma in treated group $\times 100$

Dry weight of granuloma in control group

\section{Statistical analysis}

The results were analyzed using one way ANOVA followed by post-hoc Tukey's test in SPSS 21 Software for Microsoft. The statistical significant value for any measure was set to $\mathrm{p}<0.05$ at a confidence interval of $95 \%$. The results expressed is in mean \pm standard error.

\section{RESULTS}

The animals were divided in to four group's six rats in each group for acute and subacute inflammation. Seven days gap was given between acute and subacute inflammation.

\section{Acute inflammation}

In acute inflammation the standard aspirin group showed significant reduction in paw edema when compared to low dose and high dose test groups.

The low dose test group reduced inflammation only to a certain extent which is significant when compared to the control group at the end of first hour and the percentage of edema reduction is not significant when compared with standard aspirin treated group. The high dose G. arborea group reduced the inflammation as well as paw edema which is significant when compared with control group. The high dose $G$. arborea has anti-inflammatory activity and it is comparable to the standard group (Table 2).

Table 2: Effect of various treatments on carrageenan induced paw edema.

\begin{tabular}{|c|c|c|c|c|c|c|c|}
\hline \multirow{2}{*}{ Time } & \multirow{2}{*}{$\begin{array}{l}\text { Control } \\
\text { Paw edema } \\
\text { in } \mathrm{ml} \text { (SEM) }\end{array}$} & \multicolumn{2}{|c|}{ Standard tramadol } & \multirow{2}{*}{$\begin{array}{l}\text { Low dose } \\
750 \mathrm{mg} / \mathrm{kg} \\
\text { Paw edema } \\
\text { in } \mathrm{ml} \text { (SEM) }\end{array}$} & \multirow{2}{*}{$\begin{array}{l}\text { G. arborea } \\
\text { Percentage } \\
\text { inhibition }\end{array}$} & \multicolumn{2}{|c|}{$\begin{array}{l}\text { High dose } G \text {. arborea } \\
1000 \mathrm{mg} / \mathrm{kg}\end{array}$} \\
\hline & & $\begin{array}{l}\text { Paw edema } \\
\text { in } \mathrm{ml}(\mathrm{SEM})\end{array}$ & $\begin{array}{l}\text { Percentage } \\
\text { inhibition }\end{array}$ & & & $\begin{array}{l}\text { Paw edema } \\
\text { in } \mathrm{ml}(\mathrm{SEM})\end{array}$ & $\begin{array}{l}\text { Percentage } \\
\text { inhibition }\end{array}$ \\
\hline 0.5 hour & $0.380 \pm 0.022$ & $0.225 \pm 0.012^{\mathrm{a}}$ & 47.62 & $0.315 \pm 0.014$ & 30.11 & $0.300 \pm 0.011$ & 39.33 \\
\hline 1hour & $0.506 \pm 0.018$ & $0.263 \pm 0.221^{\mathrm{a}}$ & 51.81 & $0.392 \pm 0.026^{\mathrm{a}}$ & 35.28 & $0.374 \pm 0.055^{\mathrm{a}}$ & 44.20 \\
\hline 2hour & $0.702 \pm 0.0184$ & $0.311 \pm 0.015^{\mathrm{a}}$ & 56.32 & $0.479 \pm 0.025^{\mathrm{a}}$ & 41.33 & $0.447 \pm 0.025^{\mathrm{a}}$ & 50.13 \\
\hline 3hour & $0.845 \pm 0.0168$ & $0.297 \pm 0.015^{\mathrm{a}}$ & 63.28 & $0.531 \pm 0.038^{a}$ & 47.29 & $0.378 \pm 0.089^{a}$ & 57.65 \\
\hline 4hour & $0.942 \pm 0.112$ & $0.276 \pm 0.022^{\mathrm{a}}$ & 72.66 & $0.500 \pm 0.025^{\mathrm{a}}$ & 51.26 & $0.301 \pm 0.063^{\mathrm{a}}$ & 66.01 \\
\hline 5hour & $0.782 \pm 0.263$ & $0.203 \pm 0.033^{\mathrm{a}}$ & 80.21 & $0.441 \pm 0.033^{\mathrm{a}}$ & 58.33 & $0.261 \pm 0.011^{\mathrm{a}}$ & 74.28 \\
\hline 6hour & $0.66 \pm 0.113$ & $0.18 \pm 0.051^{\mathrm{a}}$ & 93.28 & $0.371 \pm 0.017^{\mathrm{a}}$ & 67.89 & $0.244 \pm 0.002^{\mathrm{a}}$ & 87.13 \\
\hline
\end{tabular}

All values are expressed as Mean \pm SEM. ${ }^{\text {a denotes }} \mathrm{p}<0.05$ compared to control. 
Table 3: Effect of various treatments on granuloma dry weight.

\begin{tabular}{|c|c|c|c|c|c|c|}
\hline \multirow{2}{*}{$\begin{array}{l}\text { Control } \\
\text { Granuloma } \\
\text { dry weight }\end{array}$} & \multicolumn{2}{|l|}{ Tramadol } & \multicolumn{2}{|c|}{ Low dose G. arborea $750 \mathrm{mg} / \mathrm{kg}$} & \multicolumn{2}{|c|}{$\begin{array}{l}\text { High dose G. arborea } \\
1000 \mathrm{mg} / \mathrm{kg}\end{array}$} \\
\hline & $\begin{array}{l}\text { Granuloma } \\
\text { dry weight }\end{array}$ & $\begin{array}{l}\text { Percentage } \\
\text { inhibition }\end{array}$ & $\begin{array}{l}\text { Granuloma } \\
\text { dry weight }\end{array}$ & $\begin{array}{l}\text { Percentage } \\
\text { inhibition }\end{array}$ & $\begin{array}{l}\text { Granuloma } \\
\text { dry weight }\end{array}$ & $\begin{array}{l}\text { Percentage } \\
\text { inhibition }\end{array}$ \\
\hline $44.28 \pm 0.823$ & $21.36 \pm 0.236^{\mathrm{a}}$ & 40.28 & $35.22 \pm 0.258^{\mathrm{a}}$ & 31.33 & $28.66 \pm 0.136^{\mathrm{a}}$ & 36.88 \\
\hline
\end{tabular}

All values are expressed as Mean \pm SEM. ${ }^{\text {a denotes }} \mathrm{p}<0.05$ compared to control

\section{Sub-acute inflammation}

The mean dry weight of 10 days old granuloma expressed as mg percent body weights. In the control group the dry granuloma weight was 44, while in standard aspirin (200 $\mathrm{mg} / \mathrm{kg}$ ) treated group it was significantly decreased $(\mathrm{p}<0.01)$ with the mean value of $21.36 \pm 0.236$ and percentage inhibition of $40.28 \%$. Similarly, low dose $G$. arborea $(750 \mathrm{mg} / \mathrm{kg})$ and high dose $G$. arborea $(1000 \mathrm{mg} / \mathrm{kg})$ treated group exhibited decreased granuloma weight $(\mathrm{p}<0.01)$ with mean value of $35.22 \pm 0.25$, $28.66 \pm 0.13$ with percentage inhibition of $31.33 \%$ and $36.88 \%$.

The mean granuloma dry weight of aspirin, low dose and high dose $G$. arborea treated group showed significant difference $(\mathrm{p}<0.05)$ when compared with the mean granuloma dry weight of control group. It was found that, there was no significant difference $(p>0.05)$ between the high dose $G$. arborea treated group with standard aspirin group, which indicates anti-inflammatory activity high dose of $G$. arborea was comparable to aspirin in sub-acute inflammatory model (Table 3).

\section{DISCUSSION}

Edema formation due to carrageenan in the rat paw is the biphasic event. The initial phase is attributed to the release of histamine and serotonin. The second phase of edema is due to the release of prostaglandins, protease and lysosome. ${ }^{7,8}$

The second phase is sensitive to most clinically effective anti-inflammatory drugs. The edema produced after injection of carrageenan in rodents is associated with the production of several inflammatory mediators, such as bradykinin, nitric oxide, prostaglandins and cytokines. It has been found that the injection of carrageenan into the rat paw induces the liberation of bradykinin, which later induces the biosynthesis of prostaglandin and other autacoids, which are responsible for the formation of the inflammatory exudates..$^{9-11}$

The present study was carried out using different experimental inflammatory models like acute and subacute inflammation to evaluate anti-inflammatory activity of $G$. arborea. The inflammatory models in present experiment was checked using plethysmograph and granuloma model which are standard for screening agents for antiinflammatory activity.

In present study the standard drug aspirin showed significant reduction in inflammation and edema when compared with the control group. The low dose and high dose G. arborea treated group showed the significant antiinflammatory activity at the end of first hour in acute inflammatory model. The low dose group showed antiinflammatory activity only to a certain extent whereas the high dose treated group started showing notable antiinflammatory activity and reduction in the paw edema was more than $50 \%$ at the end of second hour. By the end of $5^{\text {th }}$ hour the percentage edema inhibition was $74 \%$.

In subacute inflammation the low and high dose G. arborea group showed significant percentage inhibition of granuloma when compared to the control group, but only the high dose results were comparable with the standard aspirin treated group. The results of our study were comparable to the study done by Bhabani et al. ${ }^{12}$

The anti-inflammatory activity of $G$. arborea may be because of the chemical constituent's present. Luteolin, a flavonoid and lignans isolated from roots of $G$. arborea has been reported to reduce production of pro inflammatory mediators in LPS-stimulated macrophages, fibroblasts, and intestinal epithelial cells. ${ }^{13}$ The study done by Lewis et al, in 1994 reported that $G$. arborea contain preminazole an anti-inflammatory isoxazole alkaloid. ${ }^{14}$

Alkaloids, flavonoids, lignans, tannins, iridioid glycoside and saponins were found to be present in this plant. The phenolic compounds such as flavonoids, tannins etc. are potential antioxidant and the antioxidant activity of these compounds is due to their ability to scavenge free radicals, lignans and iridous glycosides have been shown good antiinflammatory activity. ${ }^{15}$ The presence of most of the chemical constituents is found to be encouraging and indicates the therapeutic potential of the species.

\section{CONCLUSION}

Since $G$. arborea root extract was having all the qualities required for anti-inflammatory drug, it is safe to presume that this indigenous knowledge is a valid one and it can be safely used, considering its lack of toxicity for mammalian systems. However, no clear inference can be drawn at this 
stage and hence we consider the work for further extensive research.

Funding: No funding sources

Conflict of interest: None declared

Ethical approval: The study was approved by the Institutional Ethics Committee (1284/ac14/18/CPCSEA)

\section{REFERENCES}

1. Gandigawad P, Hogade AP, Patil PA, Malur PR. Effect of rifampicin, isoniazid on acute and subacute inflammation in male Wistar rats: an experimental study. Int J Basic Clin Pharmacol. 2017 Jan 19;4(4):682-5.

2. Sori RK, Poojar B, Hodlur N, Tilak A, Korde R, Gandigawad P. Evaluation of analgesic activity of sodium valproate and ethanolic extract of Vitex negundo in experimental analgesic models in wistar rats. Int J Basic Clin Pharmacol. 2018;7:2036-4.

3. Sori RK, Balaji O, Adiga S, Thomas H. Evaluation of the antipeptic ulcer activity of the seed extract of sesame (Sesamum indicum) in stress induced peptic ulcers in rats. Int $\mathrm{J}$ Basic Clin Pharmacol. 2018;7:1131-5.

4. Rafiee L, Hajhashemi V, Javanmard SH. In vitro and in vivo modulation of LPS and carrageenan-induced expression of inflammatory genes by amitriptyline. J Pharmacy Pharmacog Res. 2017;5(3):144-55.

5. Tentori L, Graziani G, Porcelli SA, Sugita M, Brenner $\mathrm{MB}$, Madaio R, et al. Rifampin increases cytokineinduced expression of the CD1b molecule in human peripheral blood monocytes. Antimicrob Agents Chemotherapy. 1998 Mar 1;42(3):550-4.

6. Turner RA. Screening Methods in Pharmacology. New York and London: Academic Press Inc;1965.

7. Vinegar R, Schreiber W, Hugo R. Biphasic development of carrageenin edema in rats. $\mathrm{J}$ Pharmacol Experimental Therapeut. 1969 Mar 1;166(1):96-103.

8. Crunkhorn P, Meacock SC. Mediators of the inflammation induced in the rat paw by carrageenin. Br J Pharmacol. 1971 Jul;42(3):392-402.
9. Henriques MG, Silva PM, Martins MA, Flores CA, Cunha FQ, Assreuy-Filho J, et al. Mouse paw edema. A new model for infl ammation? Braz J Med Biol Res. 1987;20:243-9.

10. Vinegar R, Truax JF, Selph JL, Johnston PR, Venable AL, McKenzie KK. Pathway to carrageenan-induced inflammation in the hind limb of the rat. InFed Proc. 1987;46:118-26.

11. Posadas I, Bucci M, Roviezzo F, Rossi A, Parente L, Sautebin L, et al. Carrageenan-induced mouse paw oedema is biphasic, age-weight dependent and displays differential nitric oxide cyclooxygenase-2 expression. Br J Pharmacol. 2004 May 1;142(2):3318.

12. Bhabani shankar nayak, P. ellaiah, Subas chandra Dinda, Mansi Khadanga, Haragouri Mishra, Sarala Nayak. Anti-inflammatory activity of flavonoid compound isolated from gmelina arborea fruits extract. Int $\mathbf{J}$ Applied Pharmaceut Biol Res. 2017;2(1):1-10

13. Arora C, Tamrakar V. Gmelina arborea: chemical constituents, pharmacological activities and applications. Int J Phytomed. 2017 Dec 28;9(4):52842.

14. Lewis JR. Muscarine, oxazole, imidazole, thiazole, and peptide alkaloids, and other miscellaneous alkaloids. Natural Product Rep. 1995;12(2):135-63.

15. Kulkarni YA, Panjabi R, Patel V, Tawade A, Gokhale A. Effect of Gmelina arborea Roxb in experimentally induced inflammation and nociception. J Ayurveda Integrative Med. 2013 Jul;4(3):152-7.

Cite this article as: Gandigawad P, Poojar B, Hodlur N, Sori RK. Evaluation of anti-inflammatory activity of ethanolic extract of Gmelina arborea in experimental acute and sub-acute inflammatory models in wistar rats. Int J Basic Clin Pharmacol 2019;8:128-32. 